\title{
KANDUNGAN METABOLIT SEKUNDER DAN EFEK PENURUNAN GLUKOSA DARAH EKSTRAK BIJI RAMBUTAN (NEPHELIUM LAPPACEUM L) PADA MENCIT (MUS MUSCULUS)
}

\author{
Anak Agung Gede Prawira Yuda, Rolan Rusli, Arsyik Ibrahim \\ Laboratorium Penelitian dan Pengembangan FARMAKA TROPIS Fakultas Farmasi \\ Universitas Mulawarman, Samarinda, Kalimantan Timur \\ email:prawiraaa@gmail.com
}

\begin{abstract}
ABSTRAK
Telah dilakukan penelitian dengan judul "Kandungan Metabolit Sekunder dan Efek Penurunan Glukosa Darah Ekstrak Biji Rambutan (Nephelium lappaceum L)Pada Mencit (Mus Musculus)" bertujuan untuk mengetahui metabolit skunder, aktivitas dan dosis efektif ekstrak biji buah rambutan terhadap penurunan kadar glukosa darah mencit. Hasil pengujian metabolit sekunder menunjukan bahwa biji rambutan mengandung senyawa fenol, flavonoid dan tannin. Penelitian dilakukan dengan pemberian dosis ekstrak yaitu $0,05 \mathrm{mg} / 20 \mathrm{~g}, 0,09 \mathrm{mg} / 20 \mathrm{~g}$ dan $0,18 \mathrm{mg} / 20 \mathrm{~g}$ BB Mencit, serta kontrol negatifnya $\mathrm{Na}$ CMC yang diberikan per oral setiap satu kali sehari selama 7 hari. Pengukuran glukosa dilakukan pada hari ke-0, ke-4 dan ke-8 menggunakan alat Glukosameter. Analisis data dilakukan menggunakan uji statistik ANAVA satu arah, dilanjutkan dengan uji BNJD. Hasil ANAVA satu arah dan dilanjutkan dengan BNJD menunjukan bahwa dosis 0,09 mg/BB Mencit merupakan dosis efektif sebagai penurunan kadar glukosa darah.
\end{abstract}

Kata Kunci: biji rambutan (Nephelium lappaceum L), mencit (Mus musculus L.), glukosa darah

\section{PENDAHULUAN}

Diabetes mellitus (DM) adalah gangguan metabolisme yang ditandai dengan hiperglikemia yang berhubungan dengan abnormalitas metabolisme karbohidrat, lemak dan protein yang disebabkan oleh penurunan sekresi insulin atau penurunan sensitivitas insulin. DM merupakan penyakit terpenting yang melibatkan endokrin pankreas. Utamanya meliputi gangguan metabolisme hiperglikemia. Klasifikasi "terapi" yang dianjurkan saat ini oleh American Diabetes Association terdiri dari dua tipe utama: Diabetes mellitus bergantung insulin (IDDM) dan diabetes mellitus tidak bergantung insulin (NIDDM) (Katzung, 2000).

Rambutan banyak ditanam sebagai pohon buah, kadang-kadang ditemukan sebagai tumbuhan liar.
Tumbuhan tropis ini memerlukan iklim lembab dengan curah hujan tahunan sedikitnya $2.000 \mathrm{~mm}$. Secara empiris, bagian dari rambutan memiliki khasiat antara lain pada kulit buah digunakan untuk mengatasi disentri dan demam. Kulit kayu digunakan untuk mengatasi sariawan. Daun digunakan untuk mengatasi diare dan menghitamkan rambut. Akar digunakan untuk mengatasi demam. Serta biji digunakan untuk mengatasi kencing manis (Widyaningrum, 2011).

Salah satu bagian dari rambutan yang memiliki fungsi sebagai antidiabetes adalah bijinya. Biji rambutan (Nephelium lappaceum L) ini teridentifikasi mengandung senyawa tannin dan flavanoid (Zulhipri, 2007), dimana senyawa ini merupakan senyawa yang diduga bersifat sebagai 
antidiabetes. Secara empiris masyarakat Sangatta pada umumnya biji buah rambutan digunakan sebagai antidiabetes dengan cara disangrai atau digoreng biji buah rambutan hingga warnanya menjadi kuning kecoklatan lalu biji tersebut diblender halus berbentuk serbuk. Setelah halus direbus atau langsung diseduh dengan air panas dan diminum 1-2 kali sehari.

Penelitian yang dilakukan ini bertujuan untuk mengetahui metabolit sekunder ekstrak biji rambutan, untuk mengetahui aktivitas dan dosis ekstrak biji rambutan yang efektif terhadap penurunan kadar glukosa darah mencit (MusMusculus).

\section{METODE PENELITIAN}

\section{Bahan}

Bahan yang diteliti adalah biji rambutan, pelarut metanol, aloksan, glukosa, aquadest, $\mathrm{Na} \mathrm{CMC}$, pereaksi meyer, pereaksi dragendroff, logam magnesium, asam klorida $(\mathrm{HCl})$, besi (III) klorida, asam asetat anhidrat, dan $\mathrm{H}_{2} \mathrm{SO}_{4}$.

\section{Peralatan}

Peralatan yang digunakan dalam penelitian ini antara lain labu ukur, gelas kimia, batang pengaduk, cawan porselen, corong, kertas saring, aluminium foil, lap kasar, kapas, spidol, plester, gunting, gunting bedah, stirer, holder mencit, rotary evaporator, toples kaca, timbangananalitik digital, kandang hewan coba, timbangan hewan coba, glukosameter (Gluco Dr®), glucostrip, spuit $1 \mathrm{~mL}$, spuit $5 \mathrm{~mL}$ dan LAF (Laminar Air Flow).

\section{Pengumpulan Sampel Biji Rambutan}

Kegiatan pada tahap persiapan adalah biji rambutan dikumpulkan sebanyak $2 \mathrm{~kg}$ biji rambutan segar dikeringkan dan diblender kasar.

\section{Pembuatan Ekstrak Biji Rambutan}

Pembuatan ekstrak dilakukan dengan metode maserasi menggunakan pelarut metanol. Sampel kering biji rambutan didapatkan sebanyak $469 \mathrm{~g}$ yang kemudian dilakukan proses maserasi. Biji rambutan yang siap dimaserasi dimasukkan ke dalam toples dan ditambahkan pelarut metanol, kemudian dilakukan pengadukan setiap 24 jam selama 3 hari. Filtrat yang ada ditampung kemudian diulangi sebanyak 2 kali. Filtrat yang diperoleh dengan metode maserasi dipekatkan dengan rotary evaporatory. Ekstrak kental yang diperoleh dikumpulkan, kemudian diuapkan pada suhu kamar $26{ }^{\circ} \mathrm{C}$. Setelah diuapkan didapatkan hasil ekstrak kering biji rambutan sebanyak 68 g.

\section{Pengujian Metabolit Sekunder}

Identifikasi metabolit sekunder ekstrak metanol biji rambutan dilakukan dengan cara mengamati perubahan warna dan terjadinya pengendapan menggunakan reagen kimia. Golongan metabolit sekunder yang diuji adalah alkaloid, fenol, flavonoid, saponin, tannin serta steroid dan triterpenoid. Identifikasi senyawa alkoloid menggunakan pereaksi Dragendroff dan Meyer. Identifikasi senyawa fenol dengan penambahan larutan besi (III) klorida. Identifikasi senyawa flavonoid dengan menggunakan metanol, logam $\mathrm{Mg}$, dan $\mathrm{HCl}$. Identifikasi senyawa saponin dengan menambahkan aquades lalu dikocok kuat,dan ditambahkan $\mathrm{HCl}$. Identifikasi senyawa tannin dengan penambahan $\mathrm{FeCl}_{3}$. Identifikasi senyawa steroid dan triterpenoid dengan menggunakan asam asetat anhidrat dan asam sulfat pekat. Metabolit sekunder biji rambutan dianalisis dengan cara tabulasi jika terdapat metabolit sekunder setelah penambahan reagen kimia tertentu diberi tanda positif $(+)$ dan jika tidak terdapat metabolit sekunder diberi tanda negatif (-). 


\section{Prosedur Pengujian Penurunan Glukosa Darah}

Jumlah mencit yang digunakan untuk uji ekstrak sebanyak 20 ekor mencit jantan, dengan berat badan 22-36 gram yang di bagi dalam 4 kelompok uji, masing-masing 5 ekor. Dosis yang dipakai pada penelitian ini adalah dosis $0,05 \mathrm{mg} / 20 \mathrm{~g}$ mencit, $0,09 \mathrm{mg} / 20 \mathrm{~g}$ mencit dan $0,18 \mathrm{mg} / 20 \mathrm{~g}$ BB mencit. Untuk kelompok kontrol negatif diberikan NaCMC $0,5 \%$ tanpa ekstrak biji rambutan, kemudian diberikan peroral ke hewan coba selama 7 hari.

Pada uji ini, sebelum diberikan ekstrak semua hewan coba dari keempat kelompok percobaan diberi aloksan 150 $\mathrm{mg} / \mathrm{Kg}$ BB mencit secara intraperitonial untuk menaikkan kadar glukosa darahnya. Pengukuran kadar glukosa darah dilakukan pada hari ke-0 yaitu 3 hari setelah diinduksi aloksan, hari ke-4, dan hari ke-8. Sebelum diberikan aloksan secara intraperitonial hewan uji diberi makan dan diuji KGD sebagai kadar awal. Setelah diberikan aloksan, kemudian dilanjutkan dengan uji toleransi glukosa oral. Pemberian toleransi glukosa secara oral ini tujuannya agar hewan uji mengalami diabetes. Pemberian toleransi glukosa dilakukan selama 3 hari berturut-turut dengan volume pemberian $0,5 \mathrm{~mL}$. Mencit yang telah diinduksi secara intraperitonial dan toleransi glukosa secara oral kemudian perkembangan hiperglikemia diperiksa setiap hari sampai kadar gula darahnya lebih dari 200 mg/dL (Nugroho,2006).

Pemberian ekstrak diberikan sejak mencit dinyatakan diabetes. Pengambilan darah ekor mencit dilakukan dengan cara menggosokkan kapas yang telah diberi alkohol disekitar ekor mencit, dipotong sedikit bagian ujungnya dengan menggunakan gunting bedah, dan diurut dari pangkal ekor secara perlahan agar memudahkan darah keluar. Tetesan darah pertama dibuang. Pengukuran kadar glukosa darah mencit dilakukan dengan cara meneteskan darah pada strip test yang telah dipasang pada alat Glukosameter (Gluco Dr®) hingga menutupi seluruh permukaan strip test. Kadar gula darah akan terbaca dalam waktu \pm 8 detik kemudian.

\section{Analisis Data}

Untuk analisis data, parameter yang digunakan adalah penurunan kadar glukosa darah puasa selama 7 hari dari semua kelompok atau varians dosis. Data penurunan kadar glukosa darah kelompok kontrol, kelompok dosis 0,05 $\mathrm{mg} / 20 \mathrm{~g}, 0,09 \mathrm{mg} / 20 \mathrm{~g}$ dan $0,18 \mathrm{mg} / 20 \mathrm{~g}$ BB mencit dianalisis dengan metode ANAVA satu arah pada tingkat kepercayaan $99 \%$ dan dilanjutkan dengan uji BNJD.

\section{HASIL DAN PEMBAHASAN}

\section{Metabolit Sekunder Ekstrak Biji Rambutan}

Karakteristik sampel dapat diketahui melalui tahap perlakuan yakni pengujian metabolit sekunder. Senyawa metabolit sekunder merupakan senyawa yang tidak esensial bagi pertumbuhan organisme.Senyawa metabolit sekunder merupakan produk alami atau senyawa alam yang eksistensinya tidak begitu penting dalam tubuh tapi berperan penting pada kelangsungan hidup suatu makhluk hidup.Sebagian besar tanaman penghasil senyawa metabolit sekunder memanfaatkan senyawa tersebut untuk mempertahankan diri dan berkompetisi dengan makhluk hidup lain di sekitarnya. Hasil identifikasi metabolit sekunder ekstrak biji rambutan dapat dilihat pada Tabel 1.

Berdasarkan hasil identifikasi metabolit sekunder pada Tabel 1 menunjukan bahwa ekstrak biji rambutan terdeteksi golongan metabolit sekunder senyawafenol, flavanoid dan tannin. 
Tabel 1. Identifikasi metabolit sekunder ekstrak biji rambutan

\begin{tabular}{cc}
\hline Metabolit Sekunder & Hasil identifikasi pada Ekstrak metanol \\
\hline Alkaloid & - \\
Fenol & + \\
Flavanoid & + \\
Saponin & - \\
Tanin & + \\
Steroid dan Triterpenoid & - \\
\hline
\end{tabular}

Keterangan :

Data berupa data kualitatif (-) dan (+), dimana:

$(-)$ : Tidak teridentifikasi metabolit sekunder

(+) : Teridentifikasi metabolit sekunder

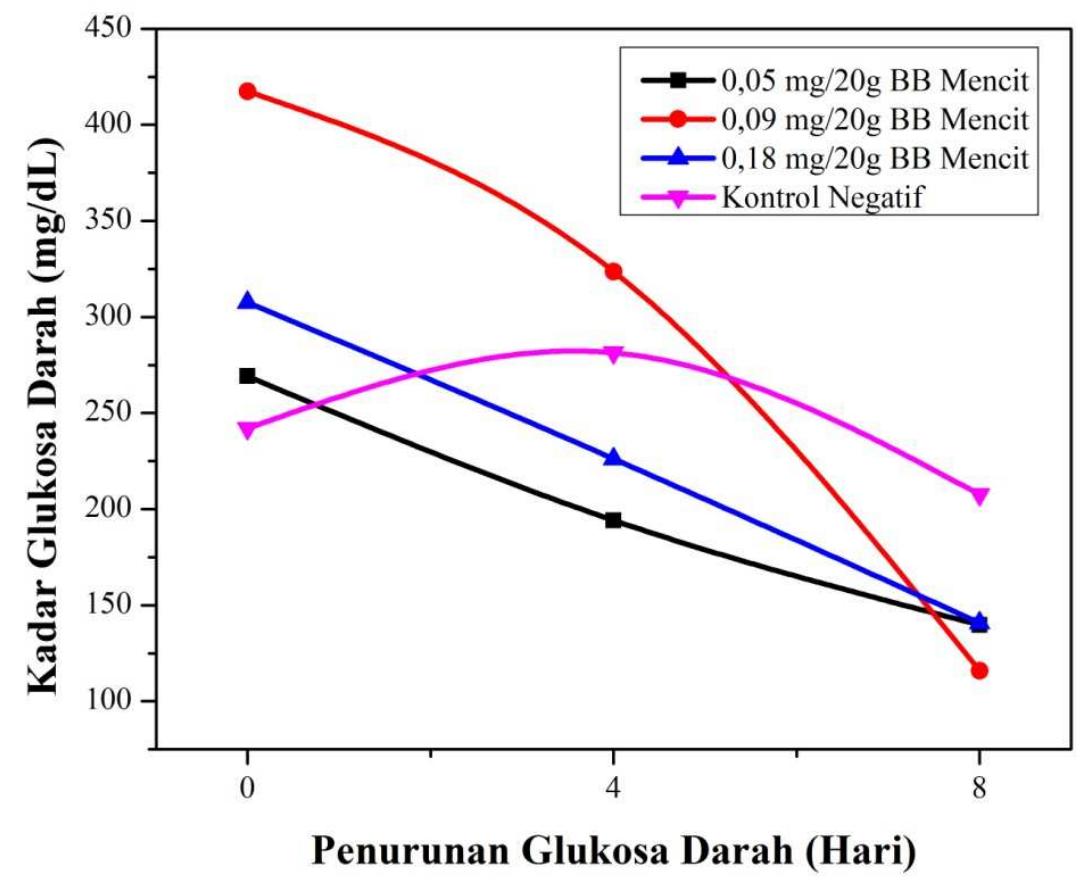

Gambar 1. Rata-Rata Penurunan Kadar Glukosa Darah Mencit (mg/dl) Per Waktu Pengambilan

\section{Aktivitas Penurunan Kadar Glukosa Darah Biji Buah Rambutan \\ Perbandingan rata - rata} penurunan kadar glukosa darah antara tiap perlakuan per tiap waktu dibandingkan dengan kontrol dapat dilihat pada Gambar 1.

Hari ke-0 pada grafik (Gambar 1) menunjukan kadar glukosa darah setelah diinduksi aloksan dan pemberian beban glukosa menunjukan peningkatan kadar glukosa darahnya. Hewan uji dikatagorikan diabetes ditandai dengan meningkatnya kadar glukosa darah melebihi normal (kadar glukosa darah $\geq$ $200 \mathrm{mg} / \mathrm{dL}$ ).

Dilihat pada grafik (Gambar 1) ekstrak biji rambutan memiliki aktivitas dalam menurunkan kadar glukosa darah, hal ini dikarenakan hampir semua variasi dosis ekstrak biji rambutan dapat menurunkan kadar glukosa darah, namun yang paling baik dalam menurunkan kadar glukosa darah untuk ekstrak biji 
rambutan adalah dosis $0,09 \mathrm{mg} / 20 \mathrm{~g} \mathrm{BB}$ mencit dibandingkan dengan dosis 0,05 $\mathrm{mg} / 20 \mathrm{~g}$ ataupun pada dosis $0,18 \mathrm{mg} / 20 \mathrm{~g}$ BB mencit.

Berdasarkan aktivitas terhadap penurunan glukosa darah pada mencit, dimana ekstrak biji rambutan memiliki aktivitas dalam menurunkan kadar glukosa darah dibandingkan dengan kontrol negatif (Gambar 1). Hal ini dikarenakan biji rambutan memiliki metabolit sekunder (Tabel 1) yang memiliki aktivitas dalam penurunan glukosa darah diantaranya adalah senyawa fenol, flavanoid dan tannin. Senyawa fenol memiliki keampuan dalam meningkatan sekresi insulin, mencegah kerusakan pada sel $\beta$ pankreas dan meningkatan fungsi dari sel $\beta$ pankreas sehingga dapat menimbulkan efek hipoglikemik pada mencit. Sedangkan flavanoid dan tannin memiliki aktivitas penurunan glukosa darah dengan cara penghambatan kerja $\alpha$-glukosidase sehingga penyerapan glukosa dan laju peningkatan gula pada sistem pencernaan masih tidak terlalu tinggi.

\section{Dosis Efektif Ekstrak Biji Rambutan Terhadap Penurunan Kadar Glukosa Darah}

Rata-rata penurunan kadar glukosa darah mencit yang di berikan ekstrak selama 7 hari dapat dilihat pada Gambar 2.

Berdasarkan (Gambar 2) ekstrak biji rambutan semua variasi dosis memberikan efek penurunan kadar glukosa darah yang lebih baik dari pada kontrol negatif. Dosis efektif ditentukan dengan menggunakan uji statistika. Model uji statistika yang digunakan adalah Uji Anava pada tingkat kepercayaan $99 \%$.

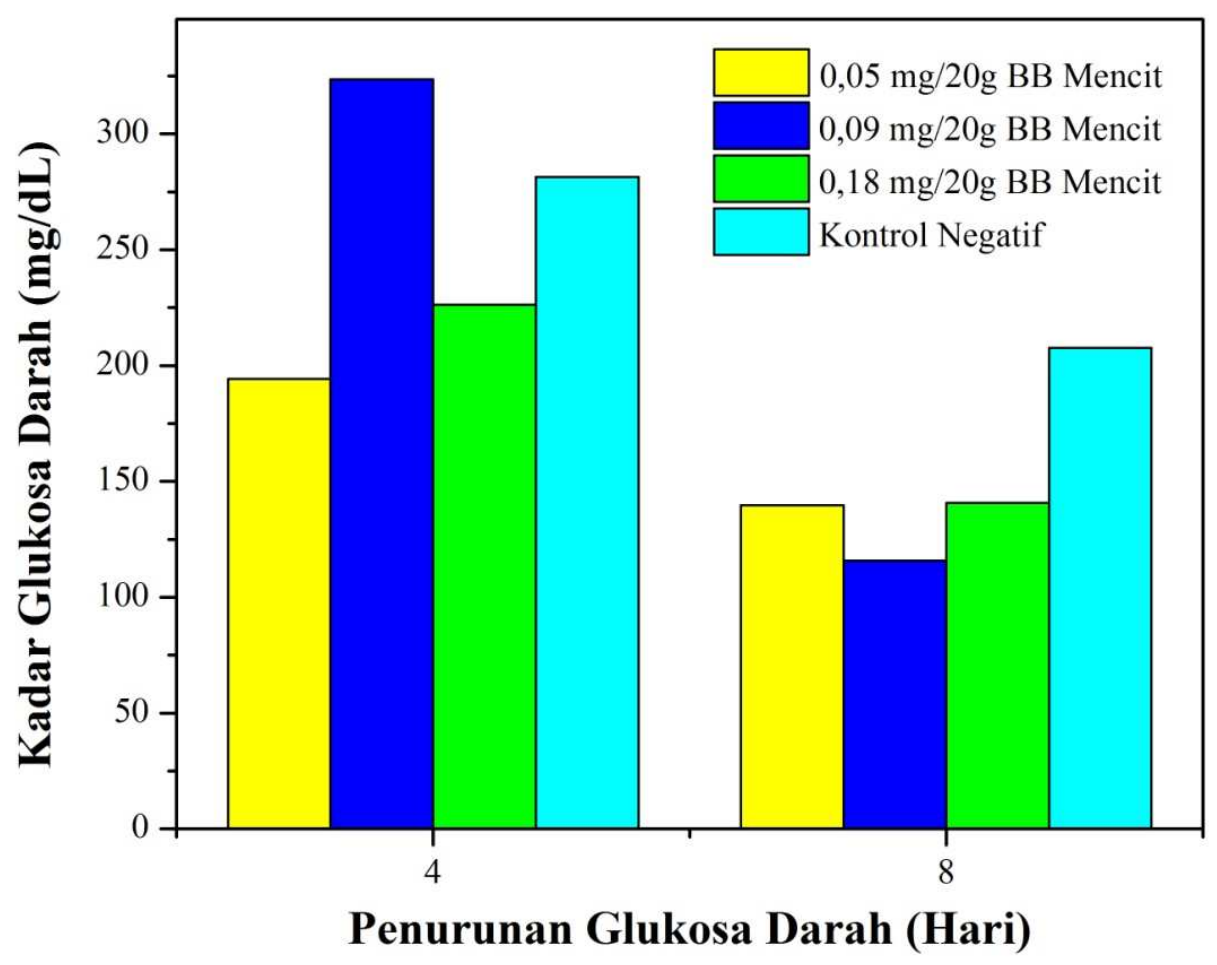

Gambar 2. Selisih rata-rata penurunan kadar glukosa darah mencit setelah 7 hari pemberian ekstrak biji rambutan 
Tabel 3. Hasil Uji BNJD

\begin{tabular}{|c|c|c|c|c|c|c|}
\hline No & Perlakuan & Rerata & $\mathrm{KN}$ & $0,18 \mathrm{mg} / 20 \mathrm{~g}$ & $0,05 \mathrm{mg} / 20 \mathrm{~g}$ & $0,09 \mathrm{mg} / 20 \mathrm{~g}$ \\
\hline \multicolumn{7}{|c|}{$\mathrm{KN}$} \\
\hline 2 & $0,05 \mathrm{mg} / 20 \mathrm{~g}$ & 102,1 & 95,2 & - & & \\
\hline 4 & $0,18 \mathrm{mg} / 20 \mathrm{~g}$ & 124,1 & 116,1 & 22 & - & \\
\hline 5 & $0,09 \mathrm{mg} / 20 \mathrm{~g}$ & 197,7 & $190,2 * *$ & 95,6 & 73,6 & - \\
\hline \multicolumn{3}{|c|}{ Standar Deviasi (Sý) } & 41,51 & 41,52 & 41,53 & 41,54 \\
\hline \multicolumn{3}{|c|}{$P(0,05.36)$} & 2,90 & 3,04 & 3,12 & 3,20 \\
\hline \multicolumn{3}{|c|}{ BNJD 0,05 (P.Sý) } & 119,97 & 126,20 & 129,52 & 132,84 \\
\hline \multicolumn{3}{|c|}{$\mathrm{P}(0,01.36)$} & 3,90 & 4,06 & 4,16 & 4,22 \\
\hline \multicolumn{3}{|c|}{ BNJD 0,01 (P.Sý) } & 161,48 & 168,54 & 172,69 & 175,18 \\
\hline
\end{tabular}

Keterangan :

* : signifikan

** : sangat signifikan

Berdasarkan uji anava nilai $\mathrm{F}$ hitung > dari F tabel $(22,41>4,38)$. Hal ini berarti bahwa pada ekstrak metanol biji rambutan dalam menurunkan kadar gula darah mencit memiliki efek yang sangat signifikan. Dalam kata lain ekstrak biji rambutan dalam menurunkan kadar glukosa darah varians dosis ekstrak tidak memiliki efek menurunkan kadar glukosa darah yang baik.

Dosis efektif ekstrak biji rambutan ditentukan dengan menggunakan uji lanjutan. Berdasarkan hasil perhitungan Koefisien Keseragaman (KK) diperoleh hasil (KK $\left.\mathrm{KK}_{\text {dosis }}\right)$ sebesar $122 \%$, maka uji lanjutan yang dipilih adalah BNJD. BNJD (Beda Nyata Jujur Duncan) merupakan uji lanjutan apabila nilai KK yang diperoleh melebihi $10 \%$.

Berdasarkan hasil dari uji lanjutan BNJD yang telah dilakukan diperoleh hasil sangat signifikan pada dosis $0,09 \mathrm{mg} / 20 \mathrm{~g}$ BB mencit terhadap kontrol negatif. Hal ini sesuai dengan Gambar 2 dan Tabel 3, dimana kelompok yang memiliki aktivitas dan menjadi dosis yang efektif dalam penurunan kadar glukosa darah paling baik pada Gambar 2 adalah kelompok dosis $0,09 \mathrm{mg} / \mathrm{BB}$ mencit.

\section{KESIMPULAN}

Kandungan metabolit sekunder dari ekstrak biji rambutan adalah golongan senyawa fenol, flavanoid dan tannin. Ekstrak biji rambutan memiliki aktivitas terhadap penurunan kadar glukosa darah dengan dosis efektif ekstrak biji rambutan adalah $0,09 \mathrm{mg} / \mathrm{BB}$ mencit.

\section{DAFTAR PUSTAKA}

1. Nugroho, Agung Endro. 2006. Hewan Percobaan Diabetes Millitus: Patologi dan Mekanisme Aksi Diabetogenik.UNS: Surakarta

2. Katzung., Bertram G. 2000, Farmakologi Dasar dan Klinik, Penerbit ECG. Jakarta

3. Widyaningrum, Herlina. 2011. Kitab Tanaman Obat Nusantara. Med Press (Anggota IKAPI): Yogyakarta.

4. Zulhipri, Irma dan Imam. 2007. Uji Fitokimia dan Aktivitas Antidiabetes Ekstrak Biji Rambutan (Nephelium lappaceum L.) dengan berbagai pelarut. Ebers Papyrus: Jakarta. 